
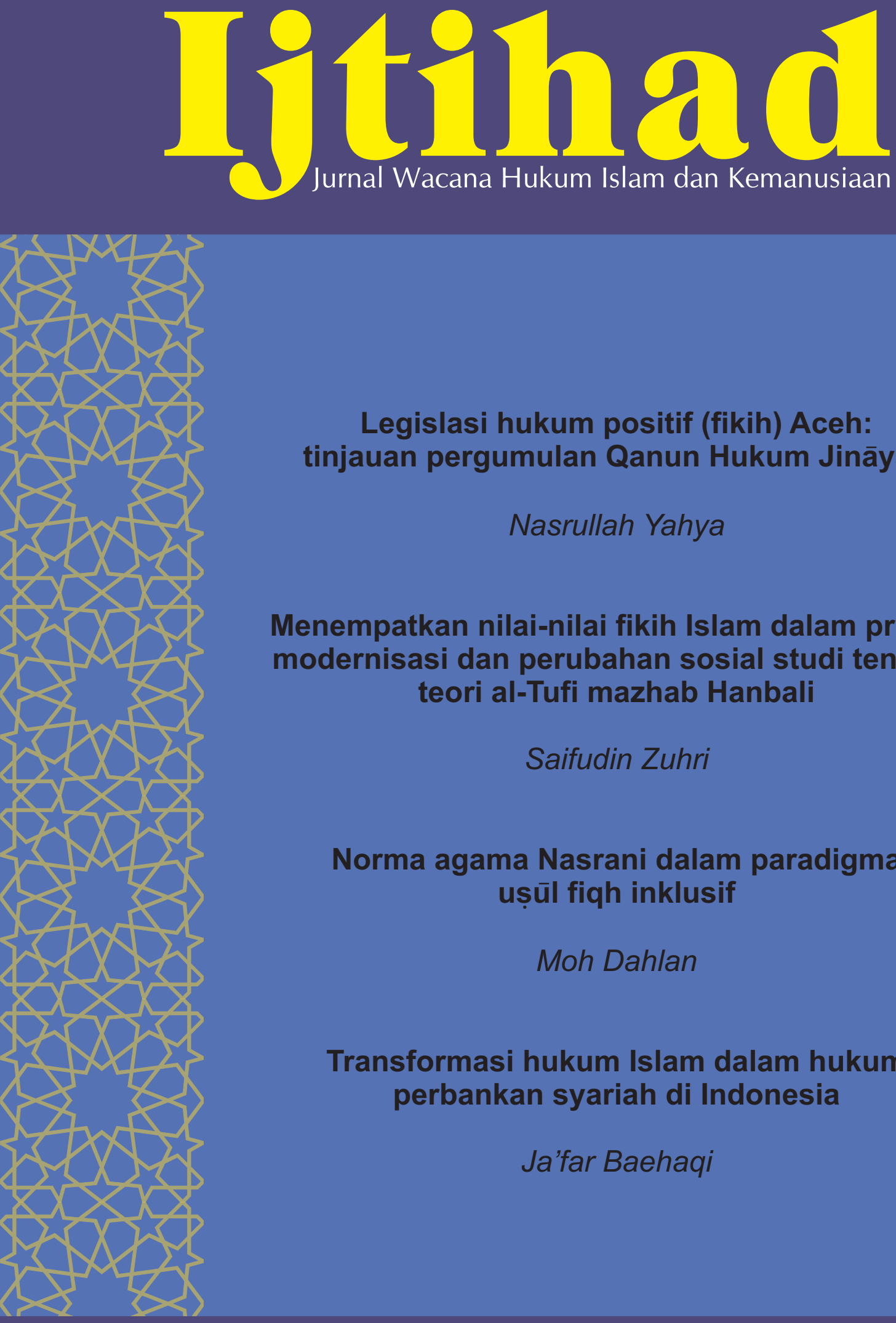

Legislasi hukum positif (fikih) Aceh: tinjauan pergumulan Qanun Hukum Jināyāh

\author{
Nasrullah Yahya
}

Menempatkan nilai-nilai fikih Islam dalam proses modernisasi dan perubahan sosial studi tentang teori al-Tufi mazhab Hanbali

Saifudin Zuhri

Norma agama Nasrani dalam paradigma ușūl fiqh inklusif

Moh Dahlan

Transformasi hukum Islam dalam hukum perbankan syariah di Indonesia

Ja'far Baehaqi 


\section{Ijtihad \\ Vol. 14, No. 2, Desember 2014}

\section{Daftar isi}

Legislasi hukum positif (fikih) Aceh: tinjauan pergumulan Qanun Hukum Jināyāh

Nasrullab Yabya • 149-166

Menempatkan nilai-nilai fikih Islam dalam proses modernisasi dan perubahan sosial studi tentang teori al-Tufi mazhab Hanbali

Saifudin Zubri • 167-187

Norma agama Nasrani dalam paradigma uṣūl fiqh inklusif

Mob Dablan • 189-209

Transformasi hukum Islam dalam hukum perbankan syariah di Indonesia Ja'far Baehaqi • 211-230

Akar, posisi, dan aplikasi adat dalam hukum

Abwan Fanani - 231-250

Bayang-bayang teori keagenan pada produk pembiayaan perbankan syariah Misnen Ardiansyah • 251-269

Dimensi politik hukum dalam perkembangan ekonomi Islam di Indonesia Bambang Iswanto • 271-284

Book Review:

Kritik otoritas pemaknaan hadis menuju masyarakat Islam berkemajuan Mubammad Irfan Helmy • 285-297 



\title{
Norma agama Nasrani dalam paradigma uṣūl fiqh inklusif
}

\author{
Moh Dahlan \\ Fakultas Syariah dan Ekonomi Islam IAIN Bengkulu \\ Alamat:Jl. Raden Fatah Pagar Dewa Bengkulu \\ E-mail:drdablan@yahoo.co.id
}

The purpose of this study is to explore the historical roots of the legal norms (religion) Islam is built by the Prophet Muhammad and also explore the norms of Christianity which became an integral part of the legal sources of usü figh inclusive paradigm. The theoretical framework of this study is to use blending approach the horizon (fushion of horizons) in the hermeneutics of Hans George Gadamer and shar' man qablana theory. The results show that there is continuity of the norms of Christianity in the development discourse of Islamic law/jurisprudence, so that the norms of the Christian religion can be a source of ușul fiqh paradigm inclusive. The character of legal norms/Islam which has the accommodative properties -in addition to corrective attitude towards ancient religions norms - be a strong indicator continuity. In this continuity, Imam Abu Hanifa, Imam Ahmad Ibn Hanbal, Muhammad Abduh, Rashid Ridla, Nurcholish Madjid and Shihab acknowledge the continuity of Christianity norms in the development of legal discourse such a ban "alcohol", the command "fasting" and " do good to others". In the context of pluralism in Indonesia, uṣul fiqh iklusif paradigm is necessary to build an inclusive legal discourse-dynamic.

Tujuan kajian ini adalah untuk mendalami akar sejarah norma hukum (agama) Islam yang dibangun oleh Nabi Muhammad Saw.. dan juga mendalami norma agama Nasrani yang menjadi bagian integral dari sumber hukum paradigma usul fikih inklusif. Adapun kerangka teori kajian ini adalah menggunakan pendekatan pembauran cakrawala (fusion of horizons) dalam hermeneutika Hans George Gadamer dan teori shar' man qablana. . Hasil kajian menunjukkan bahwa ada kontinuitas norma-norma agama Nasrani dalam pembangunan wacana hukum Islam/ fiqh, sehingga norma-norma agama Nasrani dapat menjadi sumber dalam paradigma ușul fiqh inklusif. Karakter norma hukum/ agama Islam yang memiliki sifat akomodatif -di samping sikap korektif terhadap norma agama-agama terdahulu- menjadi indikator kuat adanya kontinuitas. Dalam hal kontinuitas ini, Imam Abu Hanifah, Imam Ahmad Ibn Hambal, Muhammad Abduh, Rasyid Ridla, Nurcholish Madjid dan Alwi Shihab mengakui adanya kontinuitas norma-norma agama Nasrani dalam pembangunan wacana hukum fikih/agama Islam misalnya larangan "miras", perintah "puasa" dan " berbuat baik kepada sesama”. Dalam konteks kemajemukan di Indo- 
ljtihad, Jurnal Wacana Hukum Islam dan Kemanusiaan, Volume 14, No. 2, Desember 2014: $189-209$

nesia, paradigma uṣū fiqh iklusif ini diperlukan dalam membangun wacana hukum fikih yang inklusifdinamis.

\section{Keywords: Continuity; Christianity norms; Ușul fiqh; Inclusive}

\section{Pendahuluan}

Sejumlah konflik antara agama yang terjadi di Indonesia jelas bertetangan dengan substansi norma agama. Substansi norma agama adalah untuk menjaga dan menegakkan keselamatan atau public interest (kepentingan umum). Dalam norma hukum agama (Islam), public interest menjadi salah satu dasar penetapan hukum agama (Arifin: 2009 dan Madjid dkk, 2004: 2829), bahkan public interest dapat mengalahkan aturan tekstual. Imam al-Tufi mengatakan bahwa kepentingan umum merupakan dalil yang utama dan mengalahkan aturan ketentuan tekstual, sekalipun aturan tersebut bersumber dari ketentual tekstual (nas) al-Qur'an dan Sunnah. Jika terjadi konflik kepentingan antara kepentingan umum di satu pihak, dan ketentuan tekstual di pihak lain, maka menurut al-Tufi kepentingan umum harus didahulukan. Alasannya, kepentingan umum itulah yang menjadi maksud dan tujuan Maha Hakim (Allah), sedangkan ketentuan tekstual yang diwahyukan dan sumber-sumber nas lainnya hanyalah sarana untuk mencapai tujuan, sehingga logika hukumnya, tujuan harus mendahului perantaraan atau sarana, misalnya berbuat baik kepada sesama merupakan prinsip norma hukum/agama Islam universalyang dapat diamalkan dimana pun dan bersumber dari norma atau budaya apa pun (Rachman (ed.), 1995: 393)

Pemberlakukan prinsip-prinsip umum tersebut dilakukan oleh Nabi Muhammad Saw. melalui proses hijrah.Kebijakan hijrah Nabi tidak hanya menandakan adanya perubahan tempat dalam penerapan ajaran fikih/hukum Islam, tetapi juga adanya pergeseran penting dalam muatan misi wahyunya. Selama masa Makkah, nas-nas al-Qur'an sebagian besar mengulas dan memberlakukan nilai-nilai normatif hukum universal, tetapi sejak di Madinah mulai berhadapan dengan kasus-kasus spesifik, sehingga jawabannya juga spesifik (An-Na im, 1990: 52 dan Dahlan, 2009). Peristiwa hijrahnya Nabi Saw. menjadi era baru dalam membangun tata kehidupan keagamaan, yakni adanya inovasi tata kehidupan keagamaan dan sosial-politik yang mengagumkan bagi warga masyarakat Arab. Dalam tata kehidupan keagamaan, tidak ada warga masyarakat Arab yang dipaksa untuk konversi agama ke dalam 
agama Islam, tetapi sebalinya, seluruh kaum Muslim, pemuja berhala, kaum Yahudi dan kaum Nasrani berada dalam tali persaudaraan agama yang disebut ummah, yang berfungsi saling melindungi dan tidak boleh saling menyerang (Amstrong, 2002: 18). Dalam tata kehidupan sosial-ekonomi-politik, hak-haknya sama sebagai warga negara (Misrawi, 2010: 279).

Al-Qur'an sebagai sumber utama hukum fikih menyatakan bahwa misi agama Islam bertujuan mendukung kebenaran kitab-kitab suci yang telah ada dan pelindung kebenaran serta pembeda atau pengoreksi atas semuanya. Jadi, ada garis kontinuitas antara agama Nabi Muhammad Saw. dengan agama-agama sebelumya, termasuk agama Nasrani. Garis kontinuitas ajaran agama Nabi Muhammad Saw. dengan ajaran agama-agama sebelumnya adalah dari ajaran Nabi Ibrahim, sehingga Nabi Muhammad Saw. diperintahkan mengikuti agama yang hanif (Madjid dkk, 2004: 31). Dalam proses pemeliharaan tradisi lama yang baik (baca: kontinuitas) ini, Amir Syarifuddin menandaskan bahwa Nabi Muhammad Saw. mungkin dan boleh berijtihad sebagaimana berlaku pada manusia lainnya sesuai perintah wahyu al-Qur'an (al-Hasyr (59): 2), yang pada prinsipnya, nas tersebut memerintahkan untuk menggunakan akal pikiran dalam memahami segala keadaan, termasuk norma-norma agama terdahulu atau yang ada, sebagai perbandingan (Syarifuddin, 2009: 8-9 dan Sirry, 1995: 40). Karena itu, norma-norma hukum/agama Nabi Muhammad Saw.. juga merupakan keberlanjutan dari norma-norma agama Nasrani yang sama-sama berakar pada Nabi Ibrahim yang bertujuan memelihara kehanifan atau kemaslahatan hidup manusia. Zuhairi Misrawi (2010: 71-73), dalam karyanya yang berjudul al-Qur'an Kitab Toleransi: Tafsir Tematik Islam Rahmatan lil Alamin, menyebutkan bahwa nas al-Qur'an (12:2) menjadi bukti bahwa pilihan Tuhan atas bahasa Arab sebagai bahasa al-Qur'an menunjukkan adanya dialektika antara wahyu dan budaya. Demikian juga tafsir Nabi Muhammad Saw.. terhadap nas-nas al-Qur'an juga merupakan bagian dari dialektika budaya dan norma agama, sehingga ada proses ijtihad yang dilakukan mulai masa Nabi hingga masa kini yang harus dilakukan oleh kaum Muslimdalam menerjemankan norma-norma hukum Ilahi (Misrawi, 2010: 71-73).

Berangkat dari uraian tersebut, kajian ini merumuskan pokok masalah, bagaimana akar sejarah norma hukum (agama) Islam yang dibangun oleh Nabi Muhammad Saw.? Bagaimana norma-norma agama Nasrani dapat menjadi bagian integral dari sumber hukum 
ljtihad, Jurnal Wacana Hukum Islam dan Kemanusiaan, Volume 14, No. 2, Desember 2014: $189-209$

dalam paradigma usul fikih inklusif? Dari rumusan masalah tersebut ditetapkan tujuan kajian ini adalah untuk mendalami akar sejarah norma hukum (agama) Islam yang dibangun oleh Nabi Muhammad Saw.. dan juga mendalami norma-norma agama Nasrani yang menjadi bagian integral dari sumber hukum dalam paradigma usul fikih inklusif.

\section{Kerangka teori}

Pendekatan kajian ini adalah menggunakan teori pembauran cakrawala (fusion of horizons) dalam hermeneutika Hans G Gadamer (Kaelan, 1998: 207-209) untuk membaca pembangunan wacana hukum fikih/agama Islam yang mengalami pembauran cakrawala dalam bentuk kontinuitas dari norma-norma agama Nasrani. Oleh sebab itu, "pembaruan cakrawala" ini memiliki dua sisi sekaligus, yaitu kontiunitas dan perubahan sekaligus. Namun demikian, penelitian ini menitikberatkan pada kontinuitasnya, sehingga kerangka teori kajiannya menggunakan teori shar' man qablanā (Syarifuddin, Jilid I, 2009).

Kerangka teori kajian ini dapat digambarkan maknanya secara operasional sebagai berikut: Pertama, paradigma adalah alur berpikir yang digunakan untuk menghasilkan ilmu pengetahuan (Khun, 1970). Kedua, kata figh bermakna "paham yang mendalam". Jika makna "paham" digunakan untuk hal-hal yang bersifat lahiriyah, maka fikih bermakna paham yang menyampaikan hal-hal lahir kepada hal-hal batin (Syarifuddin, 2009: 2 dan Dahlan, 2009). Ketiga, definisi "ușūl fiqh" adalah metode yang harus ditempu oleh ulama uṣūl fiqh dalam menetapkan atau merumusan norma-norma hukum fikih/agama Islam berdasarkan dalildalil syara', sedangkan norma hukum fikih/agama Islam adalah hasil rumusan hukum syara' berdasarkan metode tersebut (Abu Zahrah, 1997: 4-5). Keempat, definisi “inklusif” dimaknai oleh kaum Ekumenis dengan penjelasan bahwa misi Gereja bukan mengkristenkan individu, tetapi memanusiakan manusia. Kelompok ini menandaskan bahwa ajaran Yesus tidak terbatas dalam tubuh gereja dan tradisinya, tetapi juga dapat dijumpai dalam tuntunan agama lain. Raimund Panikkar juga menandaskan bahwa universal reality of Yesus yang berarti, Yesus bukan hanya milik Nasrani semata, tetapi menjadi milik seluruh manusia untuk penyelematan seluruh manusia (Cosmic Christ). Dengan demikian, kata inklusif di sini adalah sikap keterbukaan tidak hanya terhadap tradisi normatif agamanya sendiri tetapi juga tradisi normatif agama lain yang diakui memiliki spirit dan tujuan yang sama (Shihab, 2005: 55). 
Dalam hal kata inklusif tersebut, teori shar' man qablana $>$ digunakan untuk membaca kontunitas norma-norma agama Nasrani dalam norma-norma hukum fikih /agama Islam, sehingga teori itu dapat digunakan untuk memberikan kriteria dalam upaya penyerapan norma-norma agama Nasrani dalam pembangunan wacana hukum fikih/agama Islam selama kriteria itu dipenuhi, yaitu (a) norma agama terdahulu (baca: Nasrani) hanya diakui jika sesuai dengan norma hukum/agama Islam; (b) norma agama terdahulu tidak dinasakh oleh norma hukum/agama Islam; (c) norma agama terdahulu diakui status hukumnya berdasarkan norma hukum/agama Islam (Zahrah, 1997: 466). Oleh sebab itu, normanorma agama Nasrani di sini dapat menjadi bagian integral dari sumber hukum Islam/fiqh dalam paradigma uṣūl fiqh inklusif.

\section{Akar historis paradigma kajian uṣūl fiqh inklusif}

Sebagian ulama berpendapat bahwa Nabi Muhammad Saw. telah mengikuti syariat yang dibawa oleh Nabi dan Rasul sebelumnya. Alasannya, sebelum menerima wahyu, ia sudah pernah melakukan thawaf di Baitullah. Amir Syarifuddin menyebutkan bahwa Nabi Muhammad Saw. sudah pernah mengikuti syariat beberapa nabi sebelumnya di antaranya: Pertama, Nabi Muhammad Saw. telah mengikuti syariat nabi Nuh as dengan alasan bahwa Nuh adalah Nabi yang paling awal menerima syariat (Q.S. Asy-Syura' [42]:13). Kedua, Nabi Muhammad Saw. telah mengikuti syariat Nabi Ibrahim dengan alasan bahwa ia adalah Nabi yang mengasaskan agama Islam (Q.S. Ali Imran [3]:67 dan 95). Ketiga, Nabi Muhammad Saw. telah mengikuti syariat nabi Musa as dengan alasan, ia adalah nabi pertama yang membawa kitab suci. Keempat, Nabi Muhammad Saw. telah mengikuti syariat nabi Isa as dengan alasan iaadalah nabi yang paling dekat masa turunnya dengan syariat nabi Muhammad Saw. (Syarifuddin, 2009: 412-414.). Mun'im Sirry dalam penelitian disertasinya yang berjudul Reformist Muslim Approaches to the Polemics of the Qur'an agaist Other Religions, yang kemudian diterjemahkan ke dalam bahasa Indonesia oleh R Cecep Lukman Yasin dengan judul Polemik Kitab Suci: Tafsir Reformasi atas Kritik al-Qur'an terhadap Agama lain, menyebutkan bahwa Nabi Muhammad Saw. bersikap bersahabat dengan dengan kaum Yahudi dan Nasrani. Bahkan Rasyid Ridla menandaskan bahwa keselamatan umat Islam, Yahudi, Nasrani dan Sabiin tidak tergantung pada afiliasi keagamaan seseorang, tetapi pada keimanan sejati yang menjadi 
ljtihad, Jurnal Wacana Hukum Islam dan Kemanusiaan, Volume 14, No. 2, Desember 2014: 189-209

kendali diri dan perbuatannya (Sirry, 2013: 16-18 dan 97).

Secara historis-normatif Qur'ani, Nabi Muhammad Saw. tidak datang untuk membatalkan norma-norma (hukum) agama-agama yang lebih lama, untuk membandingkan para nabi atau untuk memulai keyakinan baru, tetapi visi dan misi agama Nabi Muhammad Saw. sama dengan nabi Ibrahim, Musa, Daud, Sulaiman dan Isa. Nabi Muhammad Saw. juga mengetahui norma-norma agama Budha atau Hindu yang menunjukkan kebijaksanaan di kalangan pemeluknya. Karen Amstrong dalam karyanya yang berjudul Islam: Sejarah Singkat menyebutkan bahwa seluruh agama yang memiliki tuntutan yang benar dan mengajarkan keadilan pada dasarnya berasal dari sumber yang sama. Karena itu, Muhammad Saw. tidak pernah minta kaum Yahudi dan Nasrani untuk memeluk agama Islam, bahkan Muhammad Saw. terus menjalin hubungan kontinuitas dengan masa lalu dengan masa kekiniannya, sehingga tradisi spiritual misalnya tetap dipelihara, yaitu ritual adat di Ka'bah, tempat suci berbentuk kubus di jantung kota Makkah, yang menjadi pusat terpenting dalam pelaksanaan ibadah bagi umat Islam di seruluh dunia (Amstrong, 2002: 13-14)

Imam Abu Hanifah, Imam Ahmad serta sebagian pengikut Imam Syafi'i juga menyebutkan bahwa Nabi Muhammad Saw. masih mengikuti syariat sebelumnya yang sah melalui wahyu, seperti ritual ibadah haji dan umrah. Argumentasi yang digunakan mereka adalah beberapa ayat al-Qur'an berikut (Syarifuddin, Jilid I, 2009: 415).

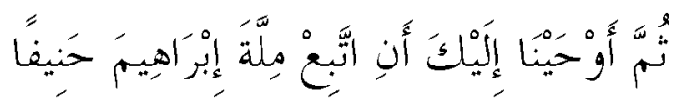

Artinya: Kemudian Kami telah mewahyukan (ayat-ayat, pen.) kepadamu: "Hendaknya mengikuti agama Ibrahim, yang hanif” (Q.S. An-Nahl [16]:123).

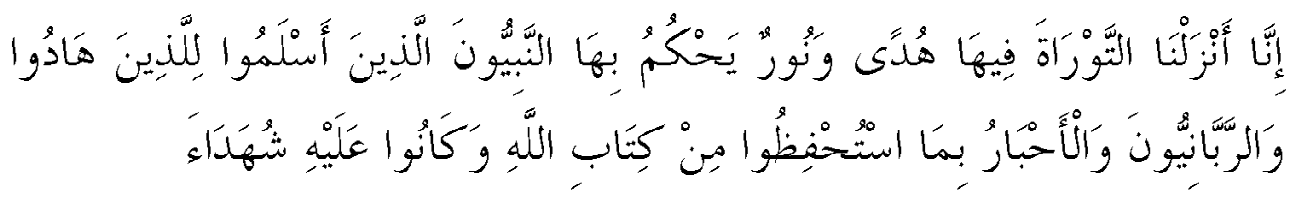

Artinya: Sesungguhnya Kami sudah menurunkan Kitab Taurat yang di dalamnya terdapatpetunjuk dan cahaya, yang dengan Kitab itu diputuskan perkara kaum Yahudi oleh nabi-nabi yang tunduk kepada Allah, oleh kaum alim mereka dan pastur-pastur mereka, dikarenakan mereka diperintah untuk memelihara kitab-kitab Allah dan menjadi 
saksi baginya (QS. al-M'idah [5]: 44) (Terjemahan Al-Qur'an merujuk kepada Terjemahan Al-Qur'an Departemen Agama RI dan Terjemahan al-Qur'an Digital)

Dalam ayat tersebut, kitab suci Taurat berisi petunjuk yang digunakan para nabi untuk menetapkan hukum dan nabi Muhammad Saw.. sebagai salah satu dari nabi yang dimaksud. Disamping itu, ada hukum seperti Qishash (QS. al-Mā'idah [5]:45) yang ditetapkan oleh nabi Muhammad Saw. berdasarkan ketentuan kitab suci Taurat. Tradisi mengikuti syariat nabi dan rasul terdahulu ini dalam kajian uṣul fiqh dikenal dengan shar' man qablanā (syariat sebelum kita), yaitu hukum-hukum yang telah disyariatkan bagi umat sebelumnya yang dibawa oleh para nabi dan rasul dan menjadi kewajiban untuk diikuti oleh umatnya. Syariat yang sudah berlaku sebelum masa Muhammad Saw. adalah misalnya ibadah puasa (Q.S. al-Baqarah [2]:183) dan syariat berkurban dari syariat nabi Ibrahim. Norma-norma fiqh tersebut sesuai dengan kaidah: shar' man qablanā shar' laña (syariat untuk umat sebelum kita, berlaku untuk syariat kita) (Syarifuddin, Jilid I, 2009: 415-420).

Muhammad Abu Zahrah menyatakan bahwa kalau syariat samawi pada dasarnya adalah satu sumber, maka secara keseluruhan harus diterimaberlakukanya dengan norma hukum/ agama Islam. Dengan demikian, hukum-hukum syariat samawi tetap berlaku sebagaimana semula (Abu Zahrah, 1997: 467). Abdul Wahab Khallaf juga mengutarakan bahwa jika alQur'an dan Sunnah memuat hukum-hukum dari hukum syariat/Islam yang disyariatkan kepada umat terdahulu melalui rasul-rasul mereka dan kemudian hal itu juga diwajibkan kepada kaum Muslm sebagaimana kewajiban umat terdahulu, maka hal itu juga menjadi syariat bagi kaum Muslim dan sekaligus menjadi undang-undang yang wajib dilaksanakan oleh kaum Muslim (shar' lanā wa qañun wäjib ittibà 'ubu) (Khallaf, t.th.: 93).

\section{Norma-norma hukum fikih/agama Islam}

Sebagai salah seorang sahabat yang ahli fikih, pandangan fikih Umar bin Khattab mampu melindungi dan menjaga hak-haknya seluruh agama-agama. Hal ini dapat dipelajari dari kebijakan hukum yang ditetapkan Umar mengenai harta rampasan perang yang tidak lagi dibagikan kepada prajurit muslim yang ikut berperang sebagaimana kebijakan sebelumnya. Dengan kebijakan ini, penduduk asli di tempat tinggalnya yang beragama non-Islam kemudian bisa menggarap harta kekayaan produktif dengan kewajiban membayar jizyah kepada 
ljtihad, Jurnal Wacana Hukum Islam dan Kemanusiaan, Volume 14, No. 2, Desember 2014: 189-209

negara(QS. al-Anfăl [8]:41). Bahkan sejak masa Abu Bakar, warga Muslim, Yahudi, Kristen dan Zoroaster mendapat status kedudukan dan perlindungan sebagai ahli kitab dalam ikatan ummah.Walaupun sempat ada gejolak pemberontakan (riddah), tetapi Abu Bakar mampu mengatasi dan memberikan perlindungan terhadap mereka yang beragama selain agama Islam (Amstrong, 2002: 35-43).

Dalam kerangka kebebasan beragama tersebut, Said Aqil Siradj menunjukkan bahwa Al-Sarakhsi -salah satu ulama salaf- dalam kitabnya al-Mabsut menyatakan bahwa abl aldhimma (agama Nasrani dan agama lainnya) tidak dilarang menjalankan ajaran agamanya dan juga tidak diarang membangun gereja yang diperlukan di desanya. Agama Nasrani dan agama lainnya memliki hak yang sama untuk hidup dan berkembang sebagaimana agama Islam di dunia Islam (Siradj, 2012). Indonesia sebagai bangsa religius juga mengakui eksistensi agama secara legal formal sebanyak enam, yaitu agama Islam, Kristen, Katholik, Hindu, Budha dan Konghucu sebagaimana dinyatakan dalam Pancasila dan UUD 1945 (UUD 1945 dan Amandemennya, t.th.: 10 dan 42). Rumusan pokok pikiran tersebut juga kemudian diatur dalam regulasi peraturan perundang-undangan, yaitu Undang-UndangRepubik Indonesia Nomor 20 Tahun 2003 tentang Sistem Pendidikan Nasional yang memiliki muatan salah satunya adalah untuk meningkatkan keimanan dan ketakwaan kepada Tuhan Yang Maha Esa.Perlakuan fiqh yang inklusif terhadap eksistensi agama lain selain agama Islam, juga ditegaskan dalam al-Qur'an yang artinya; "bagimu, agamamu, dan bagiku, agamaku”. (QS. al-Kafirun, [109]: 6). Nas al-Qur'an tersebut menjelaskan bahwa untuk menentukan eksistensi agama yang benar hanya milik Allah swt (Ta bukma illa li Allah), tidak seorang pun dapat sepenuhnya memahami kehendak dan kekuasaan Allah swt. Karena itu Nabi Saw. bersabda; "Kalian tidak tahu apa sebenarnya hukum Allah". Menurut Abdurrahman Wahid, walaupun ketentuan hukum fikih dibangun dan digali dari sumber al-Qur'an dan Sunnah, tetapi fiqih tetap merupakan hasil usaha manusia yang terikat dengan kepentingan kemaslahatan manusia yang berada dalam pusaran ruang dan waktu (Wahid, , 2011: 141)

Selanjutnya, seorang Muslim dapat memperdalam norma-norma hukum yang dibawa Nabi Isa AS saat berdialog dengan umat Nasrani/Kristen. Dari tradisi Nasrani yang kaya dengan keistimewaan, superioritas dan keunikan Nabi Isa AS, seorang Muslim dapat memantapkan ajarannya. Demikianlah ulama Muslim dapat menempatkan Isa as sebagai model 
titik pendakian spiritual ke tingkatan sbubüd dan fană'. Demikian juga umat Nasrani dapat memperoleh inspirasi dari al-Qur'an untuk memantapkan keimanannya akan kebenaran ajaran Nabi Isa AS, kebesaran dan keunikannya yang terekam dalam al-Qur'an. Al-Qur'an merupakan sumber inspirasi dalam memahami arti tauhid dalam menyingkap misteri trinitas dan sekaligus menerima Muhammad sebagai utusan Tuhan setelah Nabi Isa AS (Shihab, 2005: 58-59).

Dalam pemikiran Nurcholish Madjid, agama Nasrani (Kristen-Katolik) merupakan agama pendahulu dari ajaran agama (fikih) Islam, sehingga ajaran fikih Islam merupakan kelanjutan dari ajaran fikih agama non-Islam. Inti ajaran fikih Islam adalah kontinuitas dari inti semua ajaran fikih agama terdahulu, sebelum turunya agama Islam. Oleh sebab itu, seluruh umat pemeluk agama Allah adalah umat yang tunggal dan memiliki nilai-nilai kebenaran universal (Madjid dkk, 2004: 45). Sebagaimana ayat al-Qur'an (QS.Asy-Syuara [42]: 13) yang menandaskan bahwa Tuhan telah mengundangkan aturan syari'at agama bagi kaum Muslim sebagaimana Kitab Suci yang telah diwasiatkan kepada Nuh, Ibrahim, Musa dan Isa AS, yaitu perintah untuk menegakkan ajaran agama dan larangan berpecah belah dalam menjalankan ajaran agama.

Nabi Muhammad Saw. adalah salah seorang dari deretan para nabi dan rasul yang tampil dalam pentas sejarah umat manusia. Untuk itu, para pengikut Nabi Muhammad Saw.. diwajibkan percaya kepada para nabi dan rasul terdahulu serta kitab-kitab suci mereka. Rukun Iman dalam agama Islam mencakup kewajiban beriman kepada para nabi dan rasul terdahulu dan kitab-kitab suci mereka, sehingga penyerapan norma-norma agama Islam tidak hanya kepada aspek sosial-historis masa Nabi Muhammad Saw.. tetapi juga normanorma agama terdahulu selama sesuai dengan norma hukum agama Islam.Jika pesan ayatayat Injil relevan dan sesuai dengan norma hukum agama Islam, maka kaum Muslim berkewajiban mengikuti dan menerapkannya sebagaimana ditegaskan dalam firman Allah (Madjid dkk, 2004: 46).

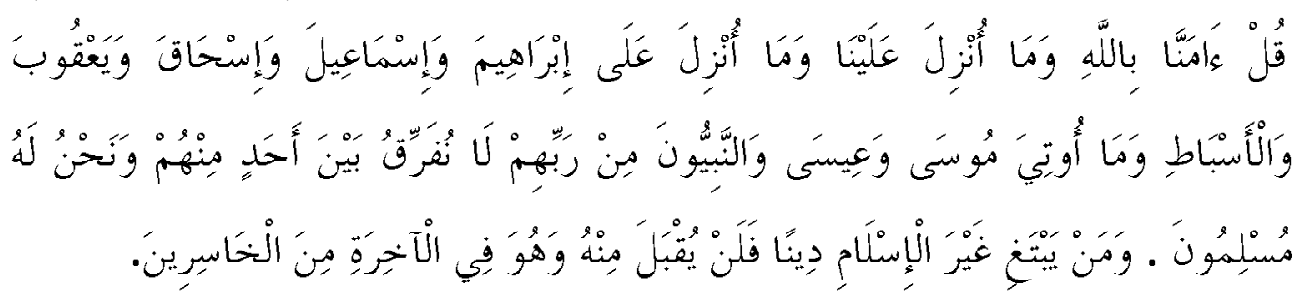


ljtihad, Jurnal Wacana Hukum Islam dan Kemanusiaan, Volume 14, No. 2, Desember 2014: $189-209$

Artinya: Katakanlah: "Kami beriman kepada Allah dan kepada hal-hal yang diturunkan kepada kami dan yang diturunkan kepada Nabi Ibrahim, Ismail, Ishaq, Ya'qub dan anak-anaknya, dan hal-hal yang diberikan kepada Musa, 'Isa dan para nabi dari Tuhan mereka. Kami tidak memperlakukan bedaseorangpun di antara mereka dan hanya kepada-Nyalah kami menundukkan diri." Siapa saja yang mencari selain agama Islam, maka tidak akan diterima daripadanya, dan ia akan menjadi bagian dari orang-orang yang rugi di akhirat (QS. Ali Imran [3]: 84-85).

Dalam pemikiran Nurcholish Madjid, agama Nasrani (Kristen-Katolik) merupakan agama pendahulu dari ajaran agama (fikih) Islam, sehingga ajaran fikih Islam merupakan kelanjutan dari norma-norma agama terdahulu. Inti ajaran fikih Islam adalah kontinuitas dari inti semua norma agama terdahulu. Oleh sebab itu, umat pemeluk agama Allah adalah umat yang tunggal dan memiliki nilai-nilai kebenaran universal (Madjid dkk, 2004: 45).Alwi Shihab juga menegaskan bahwa al-Qur'an sebagai sumber hukum fikih mengakui eksistensi umat Nasrani yang berbuat baik, berhak memperoleh pahala dari Allah swt. Al-Qur'an mengakui eksistensi norma agama-agama terdahulu dan agama non-Islam sebagaimana dijelaskan dalam firman Allah.

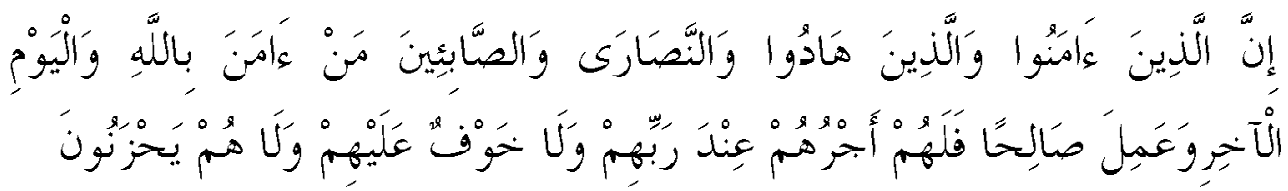

Artinya: Sesungguhnya orang-orang yang beriman, orang-orang Yahudi, orang-orang Nasrani dan orang-orang Shabiin, siapa pun diantara mereka yang beriman dengan sebenarnya kepada Allah, hari kemudian dan beramal saleh, mereka menerima pahala dari Tuhannya, tidak ada kekhawatiran bagi mereka, dan mereka tidak bersedih hati. (Q.S. al-Baqarah [2]: 62).

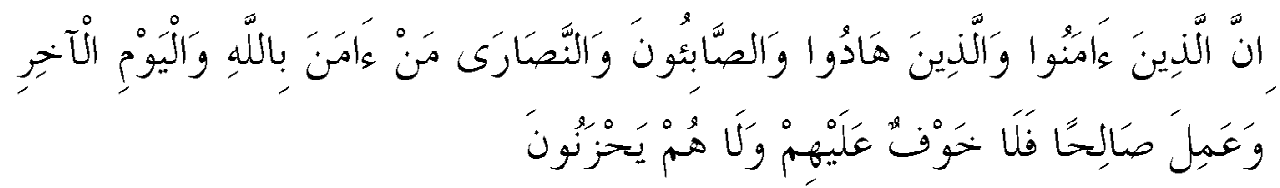

Artinya: Sesungguhnya orang-orang yang beriman, orang-orang Yahudi, Shabiin dan orang-orang Nasrani, siapa pun diantara mereka yang beriman dengan sebenarnya kepada Allah, hari kemudian dan beramal saleh, maka tidak ada kekhawatiran bagi mereka dan mereka tidak bersedih hati (Q.S. al-Mă'idah [5]: 69). 
Alwi Shihab menunjukkan bahwa Nabi Muhammad Saw. selalu menyuruh untuk saling menghormati dan menerima, terutama dengan Ahli Kitab. Agama Islam merupakan satu keluarga dalam kitab suci dengan agama Yahudi dan Nasrani, sehingga masing-masing agama memiliki kebenaran yang bisa berdialektika. Eksistensi kebenaran masing-masing norma agama diakui oleh Nabi Muhammad Saw.. dengan memerintahkan para sahabat untuk melakukan shalat untuk saudaranya yang meninggal di negara lain, yaitu Raja Najasi yang beragama Nasrani (Shihab, 2005: 108-109).

Muhammad Abduh dan Rasyid Ridla (al-Manār), al-Thabathabai (al-Mīzān) dan Muhammad Jawad Mughniyah (al-Mubin) menandaskan bahwa ayat al-Qur'an (2:62 dan 5:69) mengakui kebenaran fiqh (paham) agama Yahudi, Nasrani dan Shabiin karena mereka mamiliki asas ideologi hukum yang sama pondasinya, yaitu bersumber hanya pada Tuhan Yang Masa Esa dan pelaksanaan hukum-hukumnya dalam kehidupan sehari-hari demi terwujudkan kebajikan atau kemaslahatan (Shihab, 2005: 57).

Sejalan dengan pandangan para ulama tersebut, Nurcholish Madjid menunjukkan bahwa Nabi Muhammad Saw. mengajak kaum Ahli Kitab menuju kepada kalimat kesamaaan (kalimah sawā), yaitu menuju satu sumber kitab suci dari Allah swt. Ajakan menuju satu sumber kitab suci itu berasal dari al-Qur'an yang menandaskan bahwa Ahli Kitab hendaknya menuju kepada kalimat kesamaan (Madjid dkk, 2004: 46-47).

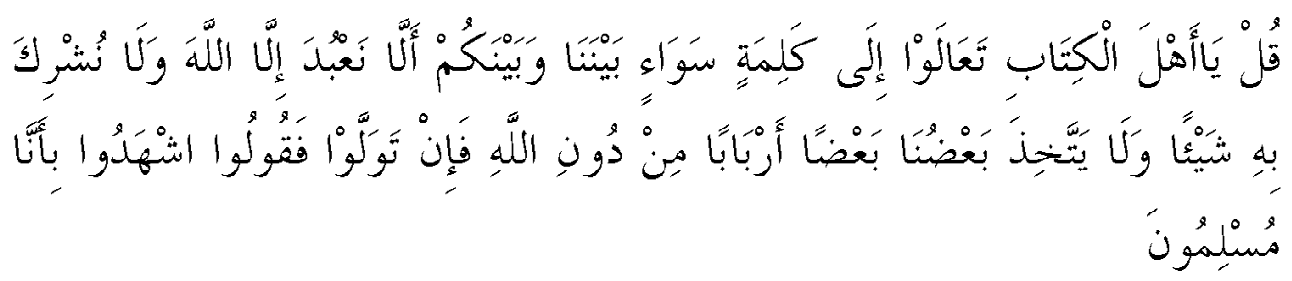

Artinya: Katakanlah: "wahai Ahli Kitab, hendaklah mennuju kepada satu kalimat yang sama antara kami dan kamu, bahwa kita tidak akan menyembah kecuali hanya kepada Allah dan kita tidak akan menyekutukan-Nya dengan sesuatupun dan sebagian kita idak menjadikan sebagian yang lain sebagai tuhan selain Allah". Jika mereka berpaling, maka katakanlah kepada mereka: "Saksikanlah, bahwa kami adalah orang-orang yang menyerah diri” (QS. Ali Imran [3]: 64). 
ljtihad, Jurnal Wacana Hukum Islam dan Kemanusiaan, Volume 14, No. 2, Desember 2014: $189-209$

Meskipun para pemeluk kitab al-Qur'an, Taurat dan Injil menyadari ada beberapa perbedaan, tetapi al-Qur'an dan kajian keagamaan modern mendukung pencarian titik pesamaan, sebab kitab-kitab suci pada prinsipnya tidak boleh dikonfrontasikan, tetapi justru perlu dicari titik-titik persamaan atau kontiunitasnya. Al-Qur'an tidak menghendaki konfrontrasi itu, karena kitab suci kaum Muslim melihat dirinya sebagai kelanjutan yang konsisten dari Kitab Injil dan Taurat, bahkan kitab-kitab atau lembaran-lembaran (suhuf) para Nabi sebelumnya. Mengenai kitab Injil, Ibnu Taimiyah mengatakan bahwa ada kontiunitas dalam keberlakuan sebagian besar isi kitab suci tersebut bagi kaum Muslim (Madjid dkk, 2004: 55).

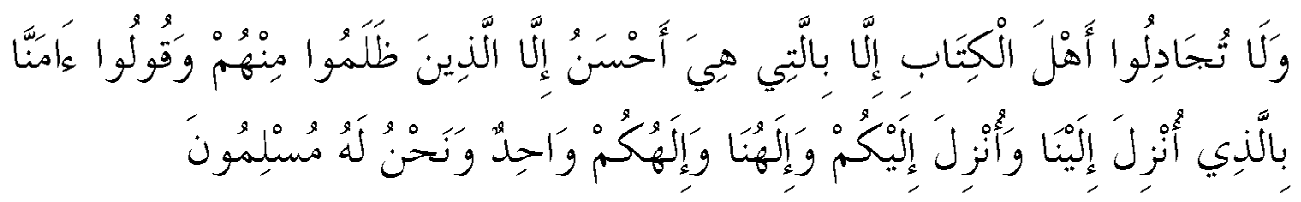

Artinya: Dan kamu janganlah berdebat dengan Ahli Kitab, kecuali dengan metode yang paling baik, kecuali bagi orang-orang zalim di antara mereka, dan katakanlah: "Kami telah beriman kepada apa-apa yang diturunkan bagi kami dan yang diturunkan bagimu; Tuhan kami dan Tuhanmu adalah satu; dan hanya kepada-Nya kami berserah diri”'(QS. al-Ankabut [29]: 46).

Dalam ayat tersebut, kaum Muslim diperintahkan untuk menyatakan kepada Ahli Kitab bahwa mereka beriman kepada ajaran yang diturunkan kepada mereka sendiri, dan yang diturunkan kepada Ahli Kitab, dan bahwa Tuhan mereka dan Tuhan Ahli Kitab adalah sama, yaitu Tuhan Yang Masa Esa dan semuanya adalah orang-orang yang pasrah (muslimun) kepada Tuhan Yang Maha Esa (Madjid dkk, 2004: 55). Al-Qur'an juga tidak mengklaim bahwa hukum suci Islam (syariat/fikih) menjadi penghapus terhadap hukum suci yang diturunkan kepada Musa dan Isa AS, karena Muhammad menganggap pesannya sesuai dengan, dan penyempurna terhadap pesan Taurat dan Injil. Lebih lanjut Alwi Shihab menyatakan.

Al-Qur'an bahkan meyakinkan kembali Muhammad tentang hal itu dalam menghadapi kaum penentang Islam Makkah: apabila kamu dalam keraguan berkenaan dengan apa yang telah Kami wabyukan kepadamu, maka bertanyalah kepada mereka yang telah membaca kitabkitab suci sebelum kamu (Q.S. Yunus [10]:94). Al-Qur'an juga mengajarkan kepada para 
penganutnya untuk bercermin kepada orang-orang yang menerima kitab suci sebelumnya demi pengetahuan dan keyakinan: bertanyalah kepada orang-orang yang memberi peringatan (ahl-dzikr) apabila kamu tidak mengetahui (Q.S.An-Nahl [16]:43). Dengan begitu, hanya karena Al-Qur'an memandang agama Kristen sebagai ekspresi keimanan yang benar dan orang Kristen sebagai pemegang iman yang sah, maka agama Kristen dapat survive di dunia Muslim (Shihab, 2005: 101).

Untuk mengungkap hubungan ideal antara Muslim dan Nasrani telah ditunjukkan oleh al-Qur'an yang tidak hanya memerintahkan untuk saling mengakui, tetapi juga saling menghormati. Muslim dan Nasrani saling berbagi dalam kesatuan Iman dan tujuan. Rasyid Ridla menyatakan bahwa Islam dan Nasrani sebagai agama wahyu tidak saling bertentangan, tetapi justru ada kontiunitas (Shihab, 2005: 102).

\section{Norma-norma hukum/agama Nasrani}

Agama Nasrani (Kristen) adalah agama yang paling luas tersebar di muka bumi dan yang paling banyak penganutnya. Satu dari setiap tiga penduduk dunia dewasa ini adalah penganut agama Nasrani. Penganut agama Nasrani berjumlah sekitar 800 juta orang. Agama Nasrani sudah berusia lebih dari 2000 tahun, ia tumbuh dan berkembang secara mengagumkan. Sejak dari sejarah kegemilangan pada upacara Misa Agung dalam Gejera Santo Petrus di Kota Roma hingga pada kesederhanaan pertemuan kaum Quaker yang penuh dengan keheningan (Smith, 2008: 355).

Pendiri agama Nasrani adalah seorang Yahudi yang bernama Yesus, yang lahir di Betlehem, Palestina, sekitar tahun 8 hingga 4 SM. Kebiasaan tradisinya menyebutkan,Yesus lahir di bulan Desember tahun pertama era Kristen, yaitu tahun 1 Masehi, tetapi tahap perkembangannya, ada beberapa koreksi dalam catatan yang menyangkut Yesus, yakni Injil, empat di antaranya terdapat dalam Perjanjian Baru diMatius, Markus, Lukas dan Yahyabahwa ia lahir selama periode Raja Herodes (L. Berkhof, Sejarah Perkembangan Ajaran Trinitas, terj. Thoriq A. Hindun, http://media.isnet.org/kristen/Sejarah/Asal-usul.html diakses 8 April 2012). Ia tumbuh dan dewasa di kota Nazareth atau di sekitarnya. Pada awal usia 30 tahun, ia mulai mengajar serta menyembuhkan orang sakit, terutama di Galilea. Seluruh perbuatan Yesus (Nabi Isa As) selama hidupnya diringkas dalam pedoman singkat, yaitu dalam lima kata yang padat "Beliau berkeliling sambil berbuat baik" (Smith, 2008: 357-359). 
Selama ini ada sejumlah pihak yang meragukan keaslian ajaran-ajaran Yesus. Dalam hal ini, sarjana Yahudi, Klausner, menyebutkan bahwa jika ada orang yang meneliti secara parsial ajaran Yesus, maka akan ditemukan padanan setiap ajaran tersebut dalam kitab Perjanjian Lama, tetapi dalam tafsirannya, kitab Talmud. Namun, jika ditelaah secara menyelusuh, ajaran-ajaran Yesus mengandung semangat pengabdian yang luhur untuk umat manusia melalui cinta kasih (Smith, 2008: 359-360)

Ajaran Yesus tidak hanya terbatas pada tubuh gereja dan tradisinya, tetapi dapat dijumpai dalam ajaran agama lain. Yesus bukan hanya milik umat Nasrani saja, tetapi juga milik seluruh umat manusia (Shihab, 2005: 55).Ajaran Yesus menandaskan bahwa umat manusia diajarkan untuk mencintai musuhnya dan berdoa untuk memohon kebaikan bagi mereka yang mengutuk. Isi nasehat-nasehat Yesus yang luar biasa mengenai bagaimana perilaku terhadap sesama manusia, yaitu ajaran-ajaran Yesus yang disusun berdasarkan paham tentang Tuhan yang mencintai manusia secara mutlak tanpa memperhitungkan nilai manusia itu ataupun kekurangannya. "Mengapa kita harus memberikan baju laur kita kepada orang lain selain baju dalam kita, jika mereka memerlukan? Karena Tuhan telah memberikan apa yang kita perlukan" (Smith,2008: 361-363).Dalam hal ini dijelaskan dalam kitab Injil yang berbunyi:

Apakah mukamu tidak akan berseri, jika engkau berbuat baik? Tetapi jika engkau tidak berbuat baik, dosa sudah mengintip di depan pintu; ia sangat menggoda engkau, tetapi engkau harus berkuasa atasnya." (Kejadian, 4:7). Belajarlah berbuat baik; usahakanlah keadilan, kendalikanlah orang kejam; belalah hak anak-anak yatim, perjuangkanlah perkara janda-janda! (Yesaya, 1:17) (http://www.jesoes.com/index.php?, diakses tanggal 8 April 2012)

Agama Nasrani juga mengajarkan puasa sebagai standar untuk menunjukkan kedekatan, kecintaan, permohonan rahmat dan ampunan kepada Tuhan Yang Maha Kuasa. Tradisi Nasrani memberlakukan ibadah puasa untuk mengikuti jejak Yesus (Isa as) yang berpuasa selama 48 hari di Sahara sebagai aksi pendekatan diri kepada Tuhan. Untuk membedakan dengan tradisi Yahudi, Rabu-Jum'at ditetapkan bagi pemeluk Nasrani awal. Dalam Perjanjian Baru, Yesus menggarisbawahi perlunya berpuasa dengan setulus hati yang dibarengi sikap mengingat Tuhan dan berlaku baik. Pada abad keempat, ketika pemeluk agama Nasrani mengalami penganiayaan, anjuran puasa Lent selama 40 hari diberlakukan ((Shihab, 2005: 152-53).Dalam hal ini, kitab Injil menerangkan. 
Dan apabila kamu berpuasa, janganlah muram mukamu seperti orang munafik.Mereka mengubah air mukanya, supaya orang melihat bahwa mereka sedang berpuasa. Aku berkata kepadamu: Sesungguhnya mereka sudah mendapat upahnya (Matius 6:16) (http:/ /www.jesoes.com/index.php? diakses tanggal 8 April 2012).

Agama Nasrani juga melarang meminum minuman keras (Lukas [21]: 34). St Paul menjelaskan bahwa tubuh manusia sebagai tempat suci,sehingga tubuh manusia harus dijaga dan dipelihara dari noda, termasuk minuman keras. Agama Nasrani ini tidak membolehkan minum-minuman keras karena hal itu dapat merusak kesehatan jiwa dan raga,juga ditemukan kutukan atas para pemabuk (Cor.5:11, 6:10).

Janganlah engkau minum anggur atau minuman keras, engkau serta anak-anakmu, bila kamu masuk ke dalam Kemah Pertemuan, supaya jangan kamu mati.Itulah suatu ketetapan untuk selamanya bagi kamu turun-temurun.(Imamat:10:9). Celakalah mereka yang bangun pagi-pagi dan terus mencari minuman keras, dan duduk-duduk sampai malam hari, sedang badannya dihangatkan anggur! (Yesaya, 5:11).Celakalah mereka yang menjadi jago minum dan juara dalam mencampur minuman keras; (Yesaya, 5:22) (http:// www.jesoes.com/index.php? diakses tanggal 8 April 2012).

Berdasarkan teks-teks tersebut, sebagian umat Nasrani menafsirkan kecaman itu sebagai larangan total untuk mengkonsumsi minuman keras (miras).Namun ada yang memahaminya secara moderat, kecaman itu hanya ditujukan bagi orang yang berlebihan minum miras (Shihab,2005: 186-187).

Gereja Metodis menunjukkan contol ideal yang melakukan "Commitment Sunday" setiap tahun yang direstui oleh Dewan Wali Gereja Amerika. Pada hari yang ditetapkan seluruh sekolah dan gereja Metodis meminta anak didik dan anggotanya, tua dan muda, untuk menandatangani janji suci untuk melakukan pantangan total terhadap semua bentuk miras. Semangat yang sama juga dilakukan oleh Gereja Presbiterian. Pada akhir abad ke-19, Majlis Umum Gereja menganjurkan pemerintah untuk melenyapkan miras dari bumi Amerika. Pada tahun 1910, gereja ini bersama gereja-gereja lain melancarkan kampanye larangan total terhadap miras (Shihab,2005: 186-187).

\section{Norma agama Nasrani}

Pada awal usia 30 tahun, Yesus melakukan kegiatan mengajar sambil menyembuhkan orang sakit, terutama di Galilea. seluruh perbuatan Yesus (Isa as) selama hidupnya dirigkas dalam 
ljtihad, Jurnal Wacana Hukum Islam dan Kemanusiaan, Volume 14, No. 2, Desember 2014: 189-209

pedoman singkat, yaitu dalam lima kata yang padat "Beliau berkeliling sambil berbuat baik" (Smith, 2008: 357=359).Kalimat ini memiliki muatan hukum keagamaan yang sangat mendalam dan dapat diamalkan oleh semua pemeluk agama, termasuk kaum Muslim. Dalam hal ini, Alwi Shihab juga menunjukkan bahwa Nabi Muhammad Saw. selalu menyuruh untuk saling menghormati dan menerima, terutama dengan Ahli Kitab sebagai satu keluarga kitab suci dengan agama Yahudi dan Nasrani (Shihab, 2005: 108-109). Dalam pandangan Nurcholish Madjid, ada kontinuitas norma keagamaan Nasrani dalam norma hukum fikih Nabi Muhammad Saw. yang dapat dibuktikan dari aspek kesamaannya (kalimah sawāa) (Madjid dkk, 2004: 46-47).

Dalam ajaran norma agama Nasrani, Yesus mengajarkan bahwa umat manusia diajarkan untuk mencintai musuhnya dan berdoa memohon kebaikan bagi mereka yang mengutuk (Smith, 2008: 361-363). Ajaran norma agama Nasrani ini dapat dilihat aspek kontinuitasnya dalam ajaran nabi Muhammad Saw. yang memerintahkan untuk mendoakan umat yang memusuhi dan juga memerintahkan umatnya untuk menyalatkan umat Nasrani yang meninggal dunia (Shihab, 2005:108-109). Upaya mengamalkan pesan-pesan norma hukum keagamaan Nasrani ini merupakan bagian dari penerapan kontinuitas dalam beragama yang kemudian menuju pengamalan norma hukum kitab suci sebelumnya sesuai dengan ajaran norma hukum fikih, seperti perintah mendoakan musuh, termasuk menyalatkan umat Nasrani dari nabi Muhammad Saw., sehingga pesan-pesan kitab suci agama Nasrani dapat juga dijadikan dasar dan diterapkan oleh kaum Muslim. Pengamalan ajaran Yesus ini merupakan kewajiban fikih Islam yang menyuruh untuk memegang teguh dan mengamalkan norma-norma kitab suci Injil sebagai bagian dari pelaksanaan dari syariat umat terdahulu (syar'u man qablana). Alwi Shihab juga menyatakan bahwa al-Qur'an juga tidak mengklaim bahwa hukum Islam (syariat/fikih) menjadi penghapus terhadap ketentuan hukum suci tersebut, karena Muhammad menganggap pesannya sesuai dengan, dan penyempurna terhadap pesan kitab suci sebelumnya, termasuk kitab Injil (Shihab, 2005:108-109).

Isi nasehat Yesus yang luar biasa mengenai bagaimana perilaku terhadap sesama manusia adalah dengan menempatkan ajaran Yesus yang disusun berdasarkan paham tentang Tuhan yang mencintai manusia secara mutlak tanpa memperhitungkan nilai manusia itu ataupun 
kekurangannya (Smith, 2008: 361-363). Dalam hal ini, al-Qur'an juga meyakinkan tentang hal ini kepada para penganutnya untuk bercermin kepada ketentuan hukum kitab suci sebelumnya demi pengetahuan dan keyakinan: bertanyalah kepada orang-orang yang memberi peringatan (ahl-dhikr) apabila kamu tidak mengetabui (Q.S.An-Nahl [16]:43). Dengan begitu, AlQur'an juga memandang agama Nasrani sebagai ekspresi keimanan yang benar dan umat Nasrani sebagai pemegang iman yang sah secara substansial(Shihab, 2005: 101).

Agama Nasrani mengajarkan puasa sebagai standar untuk menunjukkan kedekatan, kecintaan, permohonan rahmat dan ampunan Tuhan. Dalam norma hukum fikih/agama Islam, puasa juga bertujuan memperoleh taqwa walaupun teknis praktiknya berbeda, jumlah hari dan bulannya, tetapi secara substansial ada kontnuitas dari agama Nasrani kepada agama Islam mengenai tradisi berpuasa, sehingga umat manusia seharusnya mampu menghayati dan mengaktualisasikan nilai-nilai puasa, sehingga pesan substansial puasa dapat diwujudkan dalam kehidupan beragama dan berbangsa (Shihab, 2005: 152-153).

Agama Nasrani juga melarang meminum minuman keras (Lukas [21]: 34). St Paul menandaskan bahwa tubuh manusia sebagai tempat suci (Cor.5:11, 6:10). Dalam hal miras, norma hukum fikih /agama Islam melanjutkan ajaran norma agama Nasrani mengenai larangannya walaupun dengan tekanan yang lebih tegas terhadap miras (QS. 5: 90-91), sehingga di beberapa negara Islam diberlakukan syariat yang melarang minum miras (Shihab, 2005: 186-187).

Ajaran mengenai miras ini dapat diperkuat dengan analisisnya Muhammad Abduh dan Rasyid Ridla (al-Manarr), al-Thabathabai (al-Mižan) dan Muhammad Jwad Mughniyah (alMubin) yang sebelumnya sudah menandaskan bahwa ayat al-Qur'an (2:62 dan 5:69) merupakan kelanjutkan dari norma-norma agama terdahulu yang mengakui kebenaran norma-norma (hukum) agama Nasrani (termasuk Yahudi dan Shabiin) karena sama-sama memiliki asas ideologi hukum yang sama, yaitu bersumber hanya pada Tuhan Yang Masa Esa dan pemberlakuan hukum-hukumnya dalam kehidupan manusia demi terwujudnnya kebajikan atau kemaslahatan (Shihab, 2005: 57). Nurcholish Madjid juga menandaskan bahwa norma-norma keagamaan Nasrani tersebut yang sesuai dengan norma-norma agama Islam dapat dilanjutkan oleh ajaran fikih Islam untuk mewujudkan kebaikan dan kemaslahatan hidup manusia dengan menghindari miras tersebut (Madjid dkk,2004:46-47). 
ljtihad, Jurnal Wacana Hukum Islam dan Kemanusiaan, Volume 14, No. 2, Desember 2014: $189-209$

Dalam membicarakan "miras", "puasa" dan "berbuat baik kepada sesama" yang terdapat dalam norma/hukum agama Nasrani tidak boleh dikonfrontasikan, tetapi justru perlu dicari titik-titik persamaan atau kontinuitasnya. Al-Qur'an juga tidak menghendaki konfrontrasi itu, karena kitab suci al-Qur'an melihat dirinya sebagai kelanjutan yang konsisten dari kitab sebelumnya, termasuk kitab Injil. Mengenai "miras", "puasa" dan "berbuat baik kepada sesama" yang terdapat dalam ajaran agama Nasrani dapat diakui dan dilanjutkan oleh ajaran fikih Islam/Inklusif (Madjid dkk, 2004:55).

Dalam membicarakan "miras", "puasa" dan "berbuat baik kepada sesama" juga dapat dianalisis dengan pemikiran Alwi Shihab yang menegaskan bahwa al-Qur'an sebagai sumber hukum fikih dapat mengakui eksistensi pesan-pesan hukum keagamaan Nasrani tersebut dan yang mengamalkan berhak memperoleh pahal dari Allah swt. Eksistensi kebenaran pesan-pesan hukum keagamaan Nasrani tersebut dijelaskan al-Qur'an dengan menyatakan bahwa siapa pun yang mengamalkan amalan baik seperti puasa, menghindari miras dan berbuat baik kepada sesamanya akan dicatat sebagai tindakan kebajikan dan mendapatkan pahala (QS. al-Baqarah [2]: 62 dan QS. al-Ma’idah [5]: 69). Sebagai satu keluarga kitab suci dengan agama Nasrani, agama Islam mengakui eksistensi kebenaran masing-masing agama tersebut, sehingga masing-masing agama bisa saling memperkaya dan memperdalam menuju satu tujuan, yakni kemaslahatan umat atau cinta kasih. Dengan demikian di sini ada kontinuitas dari norma-norma agama terdahulu kepada norma hukum agama Islam (Shihab, 2005:108109).

Dalam membicarakan "miras", "puasa" dan "berbuat baik kepada sesama" dapat juga dianalisis dengan pemikiran figh Imam Abu Hanifah, Imam Ahmad serta sebagian pengikut Imam Syafi'i yang menyatakan bahwa Nabi Muhammad Saw. masih mengikuti syariat nabinabi sebelumnya yang sah melalui wahyu, seperti ibadah ritual haji, puasa, larangan minum khamar/miras dan keharusan berbuat baik kepada sesama (QS. al-Nahl [16]:123 dan QS. al-Ma’idah [5]: 44) (Syarifuddin, Jilid I, 2009: 415).

Dalam bahasa Hans George Gadamer, ada proses pembauran cakrawala (fushion of horizons) dalam arti, ada kontinutas dari norma-norma agama terdahulu ke dalam norma hukum fikih/agama Islam, sehingga sebagian norma/hukum agama Nasrani yang telah 
berkembang dan berlaku di masa lalu dapat diakomodir dan diakui sebagai bagian penting dari perumusan dan pembangunan hukum fikih /agama Islamselama ada kesamaan spirit dan tujuan dalam paradigma uṣūl fiqh inklusif. Tidak semua norma agama Nasrani dinasakh dan juga tidak semua diterima, di sinilah kontribusi teori fusion of horizons dapat digunakan oleh kaum Muslim dalam proses pembangunan hukum fikih /agama Islam yang berwawasan kemajemukanmelalui kerangka teori shar' man qablanā tersebut.

Dalam konteks keindonesiaan, keragaman yang menjadi ciri khas bangsa Indonesia, terutama kaum Muslim Indonesia, ditambah dengan letak geografis yang sangat strategis telah tumbuh dan berkembang sejak zaman kerajaan Nusantara. Oleh sebab itu, berdirinya NKRI didasarkan atas asas Binneka Tunggal Ika yang berarti "berbeda-beda tetapi tetap satu jua”. Dengan demikian, kesadaran bangsa Indonesia secara umum dan juga kaum Muslim Indonesia secara khusus akan hidup bersama yang majemuk sudah tumbuh dan menjadi jiwa serta semangat sejak awal mula sebelum adanya kemerdekaan RI (Pimpinan MPR dan Tim Kerja Sosialisasi MPR Periode 2009-2014, 2013: 186-187).

Berdasarkan hal tersebut, paradigma ușul fiqh inklusif sangat diperlukan oleh kaum Muslim dan bangsa Indonesia yang mayoritas Muslim. Sebab, dengan adanya paradigma inklusif tersebut, maka norma-norma hukum fikih/agama Islam yang dibangun dan diterapkan di Indonesia akan lebih toleran atas segala macam perbedaan paham, adat istiadat, madzhab hukum dan aspek lainnya. Dengan demikian, paradigma uṣūl fiqh inklusif akan memberikan sumbangan konkrit terhadap penguatan paham kemajemukan kaum Muslim dan bangsa Indonesia di dalam wadah NKRI serta untuk menangkal segala paham-paham keagamaan radikal yang sedang marak akhir-akhir ini.

\section{Penutup}

Secara global, norma hukum fikih/agama Islam yang dibangun dalam paradigma ușūl fiqh inklusif menjadikan mașlahah/perbuatan baik sebagai bagian esensialnya. Penyerapan normanorma agama terdahulu, misalnya Nasrani, merupakan bagian dari proses pembauran cakrawala dalam arti, ada kontinuitas dari norma-norma agama terdahulu ke dalam norma hukum/agama Islam dalam paradigma uṣūl fiqh inklusif. Oleh sebab itu, paradigma uṣūl fiqh inklusif dalam membangun wacana hukum fikih mengakomodir syariat nabi-nabi 
ljtihad, Jurnal Wacana Hukum Islam dan Kemanusiaan, Volume 14, No. 2, Desember 2014: $189-209$

sebelumnya (shar' man qablaña).Ada garis kontinuitas norma-norma hukm fiqh/agama Islam yang dibawa oleh Nabi Muhammad Saw. dengan norma agama-agama sebelumnyasebagaimana diakui oleh Imam Abu Hanifah, Imam Ahmad Ibn Hambal, Muhammad Abduh, Rasyid Ridla, Nurcholish Madjid dan Alwi Shihab, misalnya dalam masalah pelarangan minum khamar/anggur, keharusan berpuasa dan keharusan berbuat baik kepada sesamanya.

Implikasi kajian ini dalam kehidupan sosial-keagamaan, bahwa paradigma ușūl fiqh inklusif dapat menjadi paradigma alternatif dalam membangun wacana hukum fikih/agama Islam yang inklusif terhadap setiap dinamika perkembangan dan kepentingan umat manusia, bukan hanya spesifik untuk kaum Muslim. Secara sosial-politik hukum, paradigma ușūl fiqh inklusif dapat memberikan sumbangan dalam pembangunan wacana hukum fikih yang berbasiskan keragaman budaya dan akar normatif agama-agama di Indonesia yang berfungsi untuk memperkokoh eksistensi Negara Kesatuan Republik Indonesia (NKRI). Oleh sebab itu, paradigma ușūl fiqh inklusif harus menjadi paradigma alternatif dalam membangun wacana hukum fikih yang inklusif-dinamis di Indonesia dan juga sekaligus untuk menangkal pahampaham sesat atau radikal yang sedang marak dekade terakhir ini di Indonesia.

\section{Daftar pustaka}

Amstrong, Karen. Islam: Sejarah Singkat.terj. Fungky Kusnaendi Timur. Yogyakarta: Jendela, 2002.

An-Na'im, Abdullahi Ahmed. Toward an Islamic Reformation; Civil Liberties, Human Rights and International Law. Syracuse: Syracuse University Press, 1990.

Berkhof, L. Sejarah Perkembangan Ajaran Trinitas.terj. Thoriq A. Hindun, http:// media.isnet.org/kristen/Sejarah/Asal-usul.html diakses 8 April 2012.

Dahlan, Moh. Abdullabi Abmed An-Na'im: Epistemologi Hukum Islam. Yogyakarta: Pustaka Pelajar, 2009.

Khallaf, Abdul Wahab. Tlmu Ușül fiqh . Beirut: Dār Qalam, t.th.

Khun, Thomas S. The Structure of Scientific Revolutions, Second Edition. Chicago: The University of Chicago, 1970.

Madjid, Nurcholish, "Pandangan Kontemporer tentang Fiqh: Telaah Problematika Hukum Islam di Zaman Modern", dalam Budhy Munawar-Rachman (ed.). Kontekstualisasi Doktrin Islam dalam Sejarah. Jakarta: Paramadina, 1995.

Madjid, Nurcholish, dkk. Fiqib Lintas Agama: Membangun Masyarakat Inklusif-Pluralis. Jakarta: Paramadina dan The Asia Foundation, 2004. 
Pimpinan MPR dan Tim Kerja Sosialisasi MPR Periode 2009-2014.Empat Pilar Kebidupan Berbangsa dan Bernegara. Jakarta: Sekjen MPR-RI, 2013.

Shihab, Alwi. Islam Inklusif: Menuju Sikap Terbuka dalam Beragama. Bandung: Mizan, 2005.

Sirry, Mun'im A. Sejarah Fiqih Islam: Sebuah Pengantar. Surabaya: Risalah Gusti, 1995.

Siradj, KH. Said Aqil. Mengurai Kekusutan Keberagamaan. http://www.wahidinstitute.org/ Opini/Detail/?id=287/hl=id/Mengurai_Kekusutan_Keberagamaan, diakses 31 Maret 2012.

Smith, Huston. Agama-Agama Manusia.terj. Saafroedin Bahar. Jakarta: Yayasan Obor Indonesia, 2008.

Syarifuddin, Amir.Ușül fiqh Jilid I. Jakarta: Kencana, 2009.

Terjemahan ayat al-Qur'an mengacu pada Departemen Agama RI dan al-Qur'an Digital.

UUD 1945 dan Amandemennya. Surakarta: Al-Hikmah.

Wahid, Abdurrahman. Sekadar Mendabului: Bungan Rampai Kata Pengantar. Jakarta: Penerbit Nuansa, 2011.

Zahrah, Muhammad Abu.Ușülfigh .terj. Saifullah Ma'sum dkk. Jakarta: Pustaka Firdaus dan P3M, 1997.

http: $/ /$ www.jesoes.com/index.php?hal $=$ cari\&kata $=$ berbuat + baik $+\&$ cara $=1 \&$ bagian $=$ 3\&bahasa $=1 \&$ submit $=+$ CARI + , diakses tanggal 8 April 2012.

http:/ / www.jesoes.com/index.php?hal $=$ cari\&kata $=$ minuman + keras\&cara $=$ 1\&bagian $=3 \&$ bahasa $=1 \&$ submit $=+$ CARI + diakses tanggal 8 April 2012.

http: $/ /$ www.jesoes.com $/$ index.php?hal $=$ cari\&kata $=$ puasa\&cara $=1 \&$ bagian $=3 \&$ bahasa $=$ 1\&submit=+CARI+ diakses tanggal 8 April 2012. 